\title{
Late 'Early Intervention in Psychosis': A Family School for Learning How to Live with Schizophrenia
}

\section{Запоздалое «Раннее вмешательство при психозе»: школа жизни с шизофренией для детей и их родителей \\ DOl:10.17816/CP99}

\section{Editorial}

\author{
Heinz Katschnig, ${ }^{1,2,3}$ Peter Sint ${ }^{3,4}$ \\ ${ }^{1}$ Medical University of Vienna, Austria; \\ 2 IMEHPS.research, Vienna, Austria; \\ ${ }^{3}$ VSW-Pension Bettina, Vienna; \\ ${ }^{4}$ Austrian Family Self-Help Organisation HPE
}

The article can be used under the CC BY-NC-ND 4.0 license (c) Authors, 2021

\author{
Хайнц Качниг, 1,2,3 Питер Синт 3,4 \\ ${ }^{1}$ Медицинский университет Вены, Австрия; \\ ${ }^{2}$ Исследовательская компания «Улучшение состояния \\ здоровья населения», Вена, Австрия; \\ ${ }^{3}$ Социальный пансионат «Pension Bettina», Вена, Австрия; \\ ${ }^{4}$ Австрийская организация по вопросам семьи \\ и самопомощи
}

Лицензия CC BY-NC-ND 4.0 ( ) Коллектив авторов, 2021

\begin{abstract}
The paper describes a family school for learning how to live with schizophrenia, which was founded in 1986 in Vienna, Austria, and is still running today. It was established in cooperation between professionals and the Austrian self-help association HPE of the relatives of persons with mental disorders. It addresses the needs of 10 families at a time, in cases where a son or a daughter was diagnosed with schizophrenia and had already experienced one or several episodes of the illness. The course lasts one and a half years and is organized according to the model of a weekly boarding school, where 10 children, the "residents", stay in the school overnight from Sunday evening to Friday and take part in a structured program on cognitive, social and practical life skills. Ambulatory psychiatric treatment is taking place concurrently outside the school through local routine services. On weekends residents stay with their parents since the school is closed. Parents visit the school regularly to take part in joint activities with the residents. They also undertake night shifts in the school and attend a weekly parents' group. In the regular encounters during everyday activities in the school, "learning by doing" occurs - parents get to know the daughters and sons of other families and can learn to distinguish between disease-related and personality-related behavior. Residents can have similar learning experiences in relation to the parents of other residents. The main aim of the school is that parents learn to provide "protected autonomy" for the daughters or sons in question, in order to assist them after the end of the course in leading a life characterized by as much autonomy as possible after the end of the school.
\end{abstract}

\section{АННОТАЦИЯ}

В статье описывается основанная в Вене в 1986 году и действующая по сей день семейная школа, обучающая жить с шизофренией. Данная школа является результатом совместной работы специалистов в области психического здоровья и австрийской ассоциации взаимопомощи НРЕ, учрежденной родственниками людей, страдающих психическими расстройствами. В школе могут проходить обучение до 10 семей одновременно, при условии, если у ребенка диагностировали шизофрению и уже случались один или нескольких приступов заболевания. Курс обучения длится полтора года, он составлен по модели школы-интерната с недельным проживанием, в которой 10 «воспитанников» проживают в школе с вечера воскресенья по пятницу и в течение 
этого времени проходят структурированную программу обучения когнитивным, социальным и прикладным жизненным навыкам. Одновременно с этим за пределами школы оказывается и амбулаторное психиатрическое лечение. На выходные школа закрывается, и дети возвращаются к своим родителям. Родители регулярно посещают школу и вместе с детьми принимают участие в совместных занятиях. Они также дежурят по ночам в школе и посещают еженедельные группы для родителей. При регулярных встречах во время повседневных занятий проводится «обучение на практике» - родители знакомятся с детьми из других семей и учатся различать, какие из особенностей поведения связаны с болезнью, а какие - с его личностью. Аналогичный опыт получают и пациенты, знакомясь и проводя время с другими родителями. Основная цель школы научить родителей предоставлять детям с шизофренией «автономию с подстраховкой», чтобы после окончания курса они могли оказывать своим детям поддержку, и в то же время их ребенок мог вести максимально возможный самостоятельный образ жизни.

Keywords: schizophrenia; family; vulnerability-stress-coping model; working with families; school; early intervention in psychosis

Ключевые слова: шизофрения; семья; модель «уязвимость-стресс-преодоление»; работа с семьями; школа; раннее вмешательство при психозе

\section{INTRODUCTION}

In international guidelines, family involvement in mental health services is an essential component in the treatment of schizophrenia, but its routine implementation in the services themselves is underdeveloped. ${ }^{1}$ In this paper we report on a model of involving families as an external add-on activity to an ongoing treatment in local routine psychiatric services. It was founded jointly by professionals and a family self-help organization in Vienna (Austria) in 1986 and is still operating today. It addresses families with a child diagnosed with schizophrenia in late adolescence or early adulthood, where - after one or several clinical episodes - it has become clear that, contrary to initial hopes, the problem will not go away. It offers a one-anda-half year learning experience in a weekly boarding school setting for 10 families at a time. We (1) discuss the motives for the establishment of the school, (2) explain the framework of the boarding school setting and (3) present the learning objectives, before (4) describing the working of the school in detail. Finally, (5) a discussion section, which also addresses limitations, concludes the article. Some illustrative data are included as Supplementary materials, which can be accessed electronically.

\section{WHY A FAMILY SCHOOL FOR LEARNING HOW TO LIVE WITH SCHIZOPHRENIA?}

A diagnosis of schizophrenia leaves the family in despair - but hope exists

When in late adolescence or early adulthood a child is diagnosed with schizophrenia, the life of a family is fundamentally changed. Strange behavior might have occurred already some time before a professional diagnosis is received and treatment initiated. ${ }^{2}$ However, since the typical age of onset of schizophrenia coincides with the challenging transition period of a young person to adult life, parents might have wondered whether this was just a sign of a 'delayed puberty crisis' or due to drug use. Mental health literacy in the general population is poor and stigma and discrimination of people with mental disorders, especially with schizophrenia, are widespread. ${ }^{3}$ This makes it extremely demanding for parents and their child to accept the diagnosis of schizophrenia, which is often perceived as a virtual death sentence. Typically, a long and thorny grief process ensues, involving alternatively denial, depression and anger (akin to the processes proposed for the confrontation with one's own death), ${ }^{4}$ before it becomes clear that there is a problem that will not go away. Parents often do not easily give their child away to psychiatry, but, eventually, perhaps only after several hospitalizations and with substantial delay, the diagnosis of schizophrenia and the necessity of treatment will usually be accepted. Psychiatrists themselves may play a role in the delay since they might hesitate to communicate the diagnosis., ${ }^{3,5}$

Contrary to the public stereotype ${ }^{3,6,7}$ there is abundant evidence from long-term follow-up studies of young people diagnosed with schizophrenia for a wide spectrum of outcomes, ranging from full recovery to a chronically deteriorating course, with many patterns in between. The respective results of early studies in Switzerland 
and the US in the 1970 s and $1980 s^{8-10}$ were confirmed by more recent research. ${ }^{11-15}$ Variations in course and outcome may actually be consequences of the very imprecision of the diagnosis of schizophrenia (whose definition is still debated today), ${ }^{16,17}$ which has probably led to including heterogeneous groups of patients in these studies. The findings of these studies suggest that there is always hope that the course of the disorder in people diagnosed with schizophrenia early in life may not automatically be devastating and that recovery or a somewhat milder course are possible. Knowing of this possibility counteracts the self-fulfilling prophecy mechanism of assuming a chronically deteriorating course, where it is supposed that nothing can be done. The aim of the family school described in the present paper is to motivate and assist parents who are willing to care for their child diagnosed with schizophrenia, to find the appropriate way of dealing with the difficult situation and provide an optimal environment which enhances the chances of positive developments.

\section{Roles ascribed to parents of a child diagnosed with schizophrenia}

Probably ever since psychiatry has existed, parents of young people diagnosed with schizophrenia have been in the role of informants for psychiatrists about what had happened before the patient was admitted to hospital (as is the case in paediatrics where a child cannot speak for him/herself). After providing the information they often were (and still are today) left alone and excluded from the care process. In addition, the idea that schizophrenia was inherited gave parents an uneasy feeling and induced them to search their family trees for potential cases of schizophrenia.

When deinstitutionalization started in the 1960s and 1970s, hospital beds were reduced and patients diagnosed with schizophrenia were increasingly living near or with their families, new attention was given to parents by either blaming them for causing schizophrenia through their behavior or seeing them as victims of the disease ${ }^{18}$ (Box 1).

Following earlier psychoanalytic theories about the 'schizophrenogenic mother'19 the 1960s and 1970s saw a rise of accusations that parents were causing schizophrenia in their children by their own 'pathological' behavior, both in widespread 'antipsychiatric' publications ${ }^{20}$ and in popular films (e.g., Ken Loach's
Box 1: Role of the parents of daughters or sons diagnosed with schizophrenia as experienced in their contacts with psychiatry (1-3), as seen by themselves (4), and from the perspective of an active participant in solving problems (5)

1. Informant for psychiatrists - like a parent of a sick child in paediatrics

2. Genetic cause of schizophrenia - the biological root of the disorder

3. Blamed as being the behavioral cause of schizophrenia a perpetrator

4. Victim of the disorder - burdened by the disease

5. Active partner of professionals in solving problems "positive resignation"

Family Life, 1971). The concept of 'treating' the whole family with psychoanalytic or systemic approaches was promoted and feelings of guilt were induced or increased in many parents. The attitudes of professionals toward parents were often ambiguous or even rejecting and it was not uncommon that the separation of parents and their sick children was advocated.

With the decrease of psychiatric hospital beds, the burden of care fell increasingly on parents who were helpless in addressing daily life problems and increasingly saw themselves as victims of the disease. The burden on families came to public attention 50 years ago in England, when the father of a son who had been diagnosed with schizophrenia and discharged from hospital (in the then ongoing deinstitutionalization movement in England) published an article in the London Times describing the family's experience of caring for their son and the associated burden. ${ }^{21}$ The article resonated greatly with families in a similar situation, leading to the foundation of the 'National Schizophrenia Fellowship' (later renamed 'Rethink'; www.rethink.org) as a self-help and advocacy organization for family members and carers of people suffering from schizophrenia. ${ }^{22}$ Over the following years the idea spread to other countries and similar associations were founded elsewhere; the earliest was in 1978 in Vienna/Austria (www.hpe.at), which the authors of the present paper helped to develop (other examples are NAMI in the United States; www.nami.org and EUFAMI which covers numerous European family associations; www.eufami.org). 


\section{Box 2: Burden on parents of a daughter or son diagnosed with schizophrenia}

- $\quad$ Financial burden (e.g., giving up a job, in order to care for the patient at home)

- Health problems

- $\quad$ Fear of stigma, leading to...

- Social isolation

- Burn-out, depression

- Not knowing how to distinguish between "bad" and "mad" behavior of the daughter/son

- Not knowing how to react to cognitive disturbance, inactivity, delusions, hallucinations

- Impossible to get reliable information on the causes of schizophrenia

- Confusion about what the "correct" treatment is (medication? psychotherapy?)

- Helplessness with regard to reacting to aggressive and suicidal behavior

The problems and the burden identified in the early days were wide-ranging and left families in despair and disarray (Box 2) - and are still the same today. ${ }^{23}$ It is not only empathy for the parents which should be a motivation to assist the family, but it can also be assumed that a family in disarray cannot be a beneficial environment for a person suffering from a mental disorder characterized by cognitive, emotional and communication problems. ${ }^{24}$

\section{'Working with families': families as active partners in solving problems}

In the 1980s, so-called 'psychoeducational programs' for families were developed and evaluated. They provided information and support to families in order to better understand and cope with the illness, including information on symptoms, prognosis and treatments of the diagnosed condition. ${ }^{25,26}$ Families were not seen as causing schizophrenia, but were regarded in some approaches as responsible for relapses and needing, for instance, interventions in relation to their potential 'high expressed emotion' (high criticism, hostility and overinvolvement-the latter often fuelled by a mixture of anxiety and guilt) in order to avoid relapses. Results of these and similar studies on 'family care' in schizophrenia were promising. ${ }^{27-29}$
Inspired by these approaches and a nearly decadelong cooperation between professionals and the Austrian family self-help organization HPE, the 'Family School for Learning How to Live with Schizophrenia' was founded in $1986 .{ }^{30}$ The School (as we refer to it hereafter) combines professional knowledge and interventions with the potential of self-help resources of the families. It anticipated some elements of later developments in mental healthcare, such as attention to the early stages of schizophrenia in young people, ${ }^{31}$ the hope implied by the recovery concept,,$^{32}$ the idea of a trialogue, ${ }^{33}$ quality of life issues ${ }^{34}$ and the concepts of autonomy, inclusion and empowerment as advocated by the UN Convention on the Rights of Persons with Disabilities (CRPD). ${ }^{35}$

The approach applied in the School is not called 'family therapy' (where the family becomes the object of treatment), but 'working with families'.18 Once having accepted the diagnosis and having arrived at a kind of 'positive resignation' (Box 1 (5)) families work in partnership with the staff to find solutions to their problems, with families being seen as having needs as well as strengths. ${ }^{36}$ Working with families comprises a range of different components on a spectrum (Figure 1) extending from the pure 'professional pole' to the pure 'self-help pole', with several kinds of 'mixed activities' in between, ${ }^{18,37}$ which are specific for the School. Working
Professional Help Pole Focus on Causes, Mechanisms, Structure, Symptoms Family therapy, psychoeducation

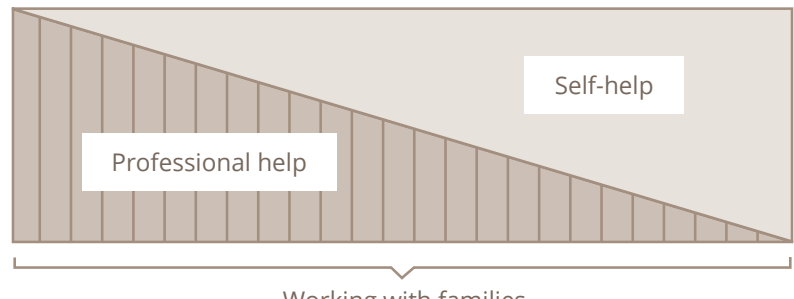

Working with families
Self-Help Pole Focus on Everyday Coping, Quality of Life Self help and advocacy groups

Figure 1. Working with families in relation to professional help and self-help 
with families in the School follows Carl Rogers' principle of 'showing unconditional positive regard' for all family members, as well as being warm, empathic and genuine. ${ }^{38}$

Since many patients diagnosed with schizophrenia become socially unattractive and have difficulties in building and keeping social relationships, parents who want to care and are willing to learn about the optimal way of doing so may be the best source of support for many patients. Parents who are members of a self-help organization usually have these characteristics, which was an important motivation for establishing the School.

Children of families participating in the program are probably at a later stage in the disease process than those usually targeted by most Early Intervention in Psychosis (EIP) programs ${ }^{31}$ and may have surpassed what has been called the 'critical period' for early intervention. ${ }^{39}$ Nevertheless, it is still early enough in life so that, considering the potentially long life ahead, 'learning how to live with schizophrenia' makes sense. This is the reason for the peculiar title we have chosen for this paper.

\section{THE GENERAL SETTING OF THE SCHOOL: A NEUTRAL LOCATION AND A NEUTRAL TIME IN A SMALL BOARDING SCHOOL PROGRAM}

During the planning process of the School several decisions were taken jointly by professionals and members of the self-help organization. First, it was decided that the School should function as a weekly 'boarding school' and that it should be established outside psychiatric services, in a 'neutral' location. Second, it was understood that enough time must be available for the learning process to take place concerning the complex needs of families, and the duration of the course was set at one-and-a-half years. Finally, it was suggested that the number of participating families should be small, to allow for the development of enduring personal contacts and mutual support. After some searching, a location was found for rent which allowed 10 families to participate simultaneously in the course.

\section{A neutral location: the School as a 'theater stage" for practising new behaviors}

Young people diagnosed with schizophrenia who are eligible for the School mostly live with their parents, for whom it is difficult to maintain the delicate balance between caring and letting autonomy grow (which is expected to increase at that stage of life). It was therefore regarded as essential that the children (hereafter 'residents') live in their own space while participating in the course. This was also regarded as providing some relief for the parents. The School was therefore set up as a weekly boarding school, where the residents would stay from Sunday evening to Friday afternoon and go home for weekends and public holidays. The residents therefore live at a 'neutral location' rather than at one of the usual two places of hospital (the 'territory' of psychiatry) or parental home (the 'territory' of parents). Each 'territory' has its own rules determined by its 'owner', but in the neutral territory of the boarding school, neither of these 'owners' dominates. Residents have their own rooms, reflecting an important aspect of autonomy (e.g., when parents visit, they have to knock at the resident's door). Parents regularly visit and take part in routine activities (also explicitly involving children of other parents). We use the image of a theater stage, where new behaviors can be 'playfully' practised without serious consequences. Residents can, without pressure, practise small steps of autonomy and parents can practise how to let autonomy happen and how solutions to problems can be found.

A neutral time: the School as 'journey' and a pause in life

It was first regarded as necessary for the program to run for two full years (including a few weeks of absence for 'vacation') to arrive at substantial changes. However, it was argued that this would deter potential residents, who would perhaps prefer to stay just one year, because they and their parents might still aim for 'success' in life, such as finishing school or getting a job. Finally, a compromise of one-and-a-half years was chosen, which has stayed the same over the last 35 years.

Overall, it is stressed already in the selection process of families that participating in the program means a pause in life and that the focus is on the learning process, which is made easier away from the pressure of the relentless progress of 'real' everyday life. It is quite difficult to convey the idea of a break in life, in which no important life changes should happen. It has proven helpful to use the image of a 'journey' among a tourist party. A journey has a preparatory stage, where in the beginning the members of the tourist party get to know one another. During the main part of the journey, the main program takes place. For the final section, 'back 


\section{Box 3: Learning objectives for both residents and parents}

- Understanding the "vulnerability-stress-coping model", "walk on a tightrope", understanding the role of medication in reducing vulnerability

- Learning the optimal way of communicating (listening skills, communication of positive and negative feelings, making requests) and aiming at simplicity, clarity and continuity in communication

- $\quad$ Structuring daily activities

- Keeping aims realistic

- Networking with other families/residents

\section{Box 4: Specific learning objectives for parents}

- Creating a non-critical, accepting environment ("protected autonomy", "intimacy at a distance")

- $\quad$ Attempting to keep behavior as a family consistent

- Creating optimal stimulation - no over-/under-stimulation (assisting a resident's "walk on a tightrope")

- Learning to cope with fluctuating insight and unpredictable behavior, with hallucinations and delusions

- $\quad$ Learning to cope with underactivity and low motivation (distinguish symptoms from "personality")

- Optimal use of professional help, accepting that sometimes no "absolutely correct" professional solution is possible

- Getting reward from daughter's/son's presence

- Learning how to take care of one's own needs

to real life' is the issue, with perhaps some sadness that the journey is over. During a journey, away from everyday life at home, usually no important life changes take place.

The long duration of one-and-a-half years allows families to experience potential changes in the clinical picture in their own and others' children. Occasionally, hospital admissions may occur, but also improvements in the clinical condition can be observed and both processes can prompt discussions about the possible reasons. One anticipated effect of the long duration was (and has proven to be correct) that some families will develop ties to one another, which facilitates mutual support after the end of the School. In fact, we have observed that families still meet one another after the end of the course and some have even set up shared flats where they continue caring for their children following the principles learned in the school.

\section{LEARNING OBJECTIVES}

In the program, schizophrenia is understood as a disorder following a 'diathesis-stress' or 'vulnerability-stresscoping model'. ${ }^{40,41}$ This implies a shift of emphasis from a fixed diagnostic entity to a dynamic process, where it is suggested that in a vulnerable individual, a stressor may trigger clinical phenomena which are characteristic of a diagnosis of schizophrenia and where interventions may reduce vulnerability or improve coping with stressors. Based on such a dynamic conception of schizophrenia in the community, the English psychiatrist John Wing suggested a list of factors which are potentially under the control of parents. ${ }^{42}$ The list was partly derived from research findings, showing that environmental factors can influence the course of schizophrenia - such as poor environmental stimulation enhancing passivity and withdrawal, ${ }^{43}$ while life events, ${ }^{44}$ 'high expressed emotion' and a critical atmosphere in families ${ }^{24}$ can trigger schizophrenic episodes. Based on this list, we have defined learning objectives and guidelines for working in the School, divided (though they partly overlap) into those relevant for the whole family (Box 3), those specific to parents (Box 4) and those specific to residents (Box 5). These objectives are mostly self-explanatory and we will only comment on a few of them here.

Given the 'environmental reactivity' of schizophrenia, John Wing (who was also a cofounder of the English selfhelp organization described above) introduced the image that a person suffering from schizophrenia and living outside hospital has to perform a 'walk on a tightrope' between under- and over-stimulation, and that one can 


\section{Box 5: Specific learning objectives for residents}

- Improving self-management

- Improving cognitive performance in daily life

- Improving daily living skills necessary for an autonomous life (cooking, cleaning, laundering, grocery shopping, handling finances...)

- Improving social and communication skills

- Learning controlled withdrawal if overstimulation looms

- Managing self-medication

- Meaningfully organizing free time ("structure")

- Learning about the problems inherent in alcohol and drug use

attempt to 'create an optimal degree of stimulation'. Too much stimulation may facilitate a psychotic relapse with 'positive' or 'plus' symptoms; ambiguous and complex communication with lack of clarity and consistency is regarded as such a stressor. Many learning objectives for parents listed in Box 4 can be subsumed under this topic. Too little stimulation may end in passivity and withdrawal (called 'negative' or 'minus' symptoms in psychopathology).

The clear and concrete message of the image of the 'walk on a tightrope' has been found to be especially useful in working with families and it is frequently advocated as a general guideline in the School. The vulnerabilitystress-coping model introduces the idea that one can also work on reducing vulnerability. It allows, for instance, to understand the role of prophylactic antipsychotic medication (an often controversial topic) ${ }^{45}$ as a means of reducing vulnerability (or increasing resistance to stress); such framing may increase acceptance of antipsychotic medication. Also, the emphasis in the School on structuring one's daily life fits into the idea of reducing vulnerability to stress. Given the cognitive and emotional disturbances in schizophrenia, learning how to create and maintain a structure in daily life is one of the objectives, which goes hand-in-hand with creating an optimal stimulation. Taking part in the course provides in itself the experience of a structure in everyday life, as will be detailed below.

The learning objectives for parents include how to properly react to specific types of psychopathological phenomena, such as hallucinations, delusions, cognitive disturbances, underactivity and lack of motivation. While difficult to apply in concrete situations, it is suggested to parents that they try to react without devaluing the resident's experiences, but also without plainly accepting them (e.g., in case of delusions: 'I accept that you see it like that, but please accept that I do not see it like that'). One of the more difficult situations for parents is to react to underactivity or low motivation. Distinguishing between disease-related underactivity, controlled withdrawal to avoid stress and 'laziness' (is the child 'mad' or 'bad'?) is often not possible and understanding the impossibility of a correct reaction is helpful as such.

Finally, perhaps the most important topic is how, at that specific stage in life when young people in general are leaving their families for an autonomous adult life, the appropriate balance can be found between 'protection' and 'letting loose', called here 'protected autonomy'. The Viennese sociologists Rosenmayer and Köckeis ${ }^{46}$ coined the term 'intimacy at a distance', which is used in the School and well understood.

While residents are in ambulatory psychiatric treatment in local routine services, the program of the School focuses on increasing skills of daily living, improving cognitive performance, learning how to avoid specific stressors (e.g., sidestepping discussions on topics related to the resident's delusional ideas) and controlled withdrawal if the environment is getting too stressful. One of the basic learning objectives is introducing structure into one's daily life.

\section{THE SCHOOL IN PRACTICE}

In the present paper, we are looking back on the experience gained from 23 completed courses over the last 35 years, during which the working of the School has not substantially changed.

\section{Location, staff and financing}

The School is located on the second floor of a traditional Viennese four-storey residential building near the city 
center, in which (on other floors) other parties are living - so it is literally located 'in the community'. It has the name 'Pension Bettina' written on its entrance, taken from the earlier function of the flat as a small hotel. We have kept this name, by which the School is well known at the local psychiatric services. The size is 340 square meters, including rooms for residents (the former hotel guest rooms) and functional rooms (living room and dining room which can also be used as a room for group activities, kitchen, bathrooms, etc.). The staff consist of four part-time psychologists, among them the head of staff (there have only been two heads of staff in 35 years, guaranteeing continuity of concept and implementation). The staff work in the School during the day from Monday to Friday following a detailed schedule, contained in a set of guidelines and working forms. Night duties during the week are carried out by parents and psychology or medical students. The School is closed on weekends. Each family is assigned a personal staff member, who acts as a case manager throughout the whole course and develops intimate knowledge about the weaknesses, strengths and needs of the family, and helps to find individual solutions. The staff receive regular psychotherapeutic supervision, not least to be able to maintain the delicate balance between professional and self-help. Finance is provided by local social service departments together with a small co-payment by the families. The legal organization running the School is a small NGO.

\section{Selecting families}

Families are referred for potential participation in the program by local psychiatric services, where the children are in treatment after one or several schizophrenic episodes have occurred. The referring services are aware of and agree with the principles of the program and inform and motivate the families to contact the School. Families are seen by School staff and are shown the rooms, including those where the residents would stay during the week. The learning objectives and methods are explained to families, as well as the concept of a long journey meaning a pause in life. While the School is focused on the whole family, it also attempts to provide a structure for assisting the residents to improve their everyday communication and social skills. However, it is stressed that the purpose of the School is not to cure the disease, but to improve the coping processes. The staff get an impression of the families, their willingness and capacity for intensive involvement and enduring cooperation. A practical issue to consider is that the travelling distance of the parents from their home to the School should not be too long, since they are required to be regularly present. Repeated visits are sometimes necessary before everyone agrees that participation is desirable and possible.

Once a decision has been made, a contract is signed by the future residents, the parents and the head of staff. From the very beginning, this introduces an element of structure and planning into the whole process. The contract contains detailed duties of everyone in the process of participating in the program (including detailed house rules). One item says that ongoing psychiatric outpatient treatment is required, detailing that the program is offered in addition to ongoing treatment in the local routine psychiatric services. The first month of the program is classed as the preparatory stage, in which important discussions take place and decisions are made which determine to some extent the work to be carried out over the following 17 months. In four out of every five participating families, the resident is a son; mothers predominate (in a few cases, both mothers and fathers are involved). The average age of the residents is around 25 years. These characteristics have not substantially changed over the decades.

\section{The time structure of the program}

The time structure of the course has per se an educational purpose, since it communicates that structure as such is essential. After the preparatory month, a warm-up phase of approximately three months follows; after all, moving into the School is a substantial change in the life routine of all participants. The main learning period runs for approximately 10 months and is followed by several months in which the main purpose is finalizing planning for life after the end of the course. The number of months for each phase is not fixed, but the sequence of the phases communicates a structure (using the image of a journey as discussed above). Throughout the whole course there is a repetitive weekly structure from Monday to Friday, with the School closed on weekends and on public holidays. Finally, there is a daily structure, with activities mainly taking place in the morning and mainly free time in the afternoon. 
Box 6: Essential activities in the school according to proximity to the professional and

the self-help pole (see Figure 1)

a) Activities near the professional pole - "psychoeducational" activities

- For residents: groups for day and weekend planning, cognitive training, music therapy

- For each individual family: six sessions of communication training during the midterm

- $\quad$ For parents as a group: Occasionally an external expert provides information in the weekly parents' group

b) "Learning by doing" activities - organized, task oriented routine activities with joint participation and encounters between residents and parents of different families, as well as staff, for practicing new behavior ("in vivo learning", "vicarious learning")

- $\quad$ Each morning three parallel household chore groups

- Weekly excursion

- $\quad$ Night shift by parents (being alone in the school with all residents)

c) Activities near the self-help pole - free time to be structured by residents and families themselves

- $\quad$ For residents: free time in the afternoons and evenings (Monday through Thursday)

- $\quad$ For residents and parents: free time on weekends and public holidays

- $\quad$ For parents: weekly parents' group for sharing information and mutual support

\section{Essential activities}

The different activities taking place each week from Monday to Friday and those expected to take place on weekends when the School is closed are listed in Box 6 and described below. To understand how the School works, it is important to explain these activities in detail. In line with the concept of 'working with families' they are classified into three groups, considering the degree of professional involvement (Figure 1). Everyone is repeatedly reminded to show unconditional regard for one another in all activities, emphasizing existing strengths of the other person and cautiously communicating identified weaknesses. All activities where residents are involved are organized in such a way that they are short and that frequent breaks are possible.

\section{a) Activities near the professional pole: 'psychoeducational' activities}

For residents (participants: residents and staff) Most residents suffer from negative and cognitive symptoms, which are known to be related to deficits in communication and social skills in everyday functioning. ${ }^{47}$ Several group activities with residents addressing these issues take place routinely during the week. They are somewhat similar to programs of psychiatric day services and also convey the idea of a structure and the need for planning one's activities. Each morning, a planning group for the day is run by a staff member; on Friday early afternoon, a similar group takes place for planning the weekend. Once a week in the afternoon, rules of living together in the School are discussed in a 'house meeting'. In addition, once a week, a cognitive training session takes place using the 'Integrated Psychological Therapy' (IPT) program that combines neurocognitive and social cognitive interventions with social skills approaches. ${ }^{48}$ Finally, once a week, the whole group of residents attends a music therapy session outside the School.

\section{For individual families (participants: resident, his/} her parent(s) and staff)

The staff member assigned to a family holds training sessions on communication skills with each individual family by using modules developed by Falloon and colleagues. ${ }^{41}$ Topics include, among others, listening skills, making positive requests and communication of positive and negative feelings. Altogether, six training sessions are held during the midterm of the course, i.e., at a time when the specific problems of each family are well known to the staff, especially to the assigned staff member responsible for the family.

For parents as a group (participants: parents, staff, external expert)

Occasionally the parents' group, taking place on Tuesday evenings (see (c) below), is attended by an invited expert providing information on specific topics, mainly medical and psychiatric and discussing questions of the parents. 
b) 'Learning by doing' activities: organized, task-oriented routine activities with joint participation and interaction between residents, parents and staff, to practise new behavior ('in vivo learning'; 'vicarious learning')

One of the main features of the program is that the structure permits and facilitates interactions between residents and parents from different families in tasks such as grocery shopping, cooking, cleaning and laundering, on joint excursions and in the evenings when a parent is on night duty. The crucial issue is that parents also meet and interact with a child from a different family and thereby learn to distinguish better between behavior related to the disease and related to the personality. This gives them a frame of reference to better understand the behavior of their own child. Such contacts occur frequently during the one-and-a-half-year program. In the weekly parents' group (see (c) below) information is shared on observations made in these activities, often with surprising insights. For example, a mother experiencing her son as inactive on weekends at home may be astonished to hear the positive feedback from another mother who worked with the son in a cooking group during the previous week, thereby getting a feeling for the relevance of situational and environmental factors for specific behaviors. It becomes apparent how the long common history of children and parents can shape behaviors or can colour the perception of each other's behavior. What is true for parents is also true, mutatis mutandis, for residents, since they can experience cooperating and communicating with other parents, which provides a new perspective on their own parental relationship.

Household chore groups with a few residents and a parent (participants: residents, parents, staff) These groups take place each morning from Monday to Friday and provide a unique opportunity for residents to cooperate with other residents on concrete tasks (the composition of the groups is changed every week). When a parent is available, there is also the opportunity for different residents and parents to cooperate and communicate with one another. The tasks include cleaning public rooms (for residents with cognitive disturbances, clear instructions are detailed in a note on the wall in each room), grocery shopping for meals (learning how to handle money and payments) and cooking meals (simple recipes have been compiled in a cookbook, with an emphasis on cheap and healthy food to prevent later resorting to fast food). The household chore groups also enable residents to learn self-management and thereby achieve more autonomy after leaving the School.

Night shifts (participants: residents, a parent or a student)

There is a special room in the School where a parent stays once a month for a night shift. No staff are present at night, but there is always a staff member on call. Letting parents make night shifts has two purposes. First, it lets them experience responsibility not only for their own child, but also for others' children. In the beginning some fears exist, but parents gradually become less fearful and experience an increase in confidence in their own decision capabilities. Second, parents arrive in the early evening and mix with residents which leads to experiences of interaction with different residents enabling 'vicarious learning'. Since there are more than 20 night shifts necessary per month and only 10 participating families, psychology and medical students take the remaining shifts. Through their interaction with residents, they introduce an element of normality into the School. Residents appreciate the presence of students to a large degree (see Supplementary materials).

Weekly excursion (participants: residents, parents, staff)

Once a week, on Wednesday afternoon, an excursion takes place with the whole group. Residents and parents participate in the planning process. In summer, outdoor activities prevail (e.g., going to an openair swimming pool) and in winter, indoor activities dominate (e.g., visits to a museum or cinema). Again, residents and parents of different families can experience each other's behavior in a normal routine setting.

\section{c) Activities near the self-help pole: free time to be structured by residents and families}

Residents and families are purposely given abundant free time during the program. They are encouraged and 'nudged' by the staff to learn how to structure free time on their own and avoid withdrawal of the residents, which is always a potential problem in schizophrenia. Once the course finishes, it will be necessary to maintain a structure, hopefully in meaningful activities, e.g., in schooling, occupational training, or a job. However, 
this may often not be possible immediately and how to have a day structure needs to be learned, to uphold the optimal balance between under- and overstimulation. This is continuously encouraged by the staff during the whole course and the free time provides opportunities to practise how to structure one's time. Ideas and examples of how this can be achieved are discussed in other activities of the School. It has repeatedly become apparent how creative families can be if they have space and the time to develop and practise new ideas.

Free time for residents in the afternoons and evenings (Monday to Thursday)

Residents have free time after lunch until around $5 \mathrm{pm}$, when specific group activities take place (see (a) above). The staff encourage residents to carry out activities during that free time, preferably outside the School and with other residents. Often, however, especially in the first months of the course, residents withdraw to their rooms and rest. This withdrawal is initially accepted by the staff, as the morning household chore groups can be quite demanding. Over time, staff increasingly encourage residents 'to do something' and the understanding of 'withdrawal' as a time-limited strategy against overstimulation (called 'controlled withdrawal') is emphasized. In the evenings, residents are encouraged to go out (e.g., to a cinema or to meet friends), preferably with other residents. This happens more frequently with the passing of time.

Free time for residents and parents on weekends and public holidays

Since the School is closed and staff are not available on weekends and public holidays, residents and parents are on their own. At the beginning of the course, parents report that many residents stay inactive and sleep during the day. This can initially be interpreted as recovery from the strain of taking part in the weekly program. Over time, some residents may meet one another for common activities, parents do the same and a resident may even stay overnight in another resident's home. The closing of the School on weekends also keeps parents involved so that the transition at the end of the course is less complicated. In the event that any crisis intervention is needed on weekends, families must call the available local emergency services (and thus learn how these services work). Finally, every time residents return to the School on a Sunday evening (this occurs at least 70 times during the program) they are learning how to leave home. For some, this is an exercise for potentially living autonomously after the program. In addition to weekends and public holidays, families are encouraged to take a vacation of 15 working days with their child.

Weekly parents' group (participants: parents, staff; occasional external experts)

This group takes place once a week on Tuesday evenings between 7:30 and $9 \mathrm{pm}$. Tuesday was chosen so that parents can report on their experiences with the residents from the preceding weekend. The purpose is to share information, give feedback and provide mutual support. A wealth of topics is discussed (as listed in Boxes 1-5), particularly experiences of cooperation and contacts with residents of other parents in the organized activities during the week. An important function of the group is the experience of not being alone with the challenge of having a child with schizophrenia. Showing comfort for and helping each other is a powerful factor for helping oneself. Friendships may develop and may remain after the end of the course. One other important feature is that parents give feedback to one another about what they can do for themselves, instead of completely sacrificing themselves for their children. The group is always attended by two staff members, who avoid direct interference but, when appropriate, provide remarks on specific topics and behaviors in the sense of a 'guided discovery' approach, i.e., helping parents to become aware of certain aspects of their behavior. On several occasions, a psychiatrist joins the group to provide information on medical issues, especially on medication, which is always a hot topic (this is a psychoeducational component of the program; see (a) above). The group session often tends to run beyond 90 minutes and it may occur that parents continue the discussion in a pub. Given the many sensitive topics discussed, it is agreed that all information received about other families remains in the group.

\section{DISCUSSION AND LIMITATIONS}

Due to a lack of resources and scepticism among professionals, the involvement of families is not yet routine in psychiatric services, as a recent review has shown. ${ }^{1}$ The authors conclude that the involvement of families may require a cultural and organizational 
shift, since family work can only be implemented if it is considered a shared goal of all members of a clinical team or mental health service. The approach of the School is one possibility of providing - as an addon component - assistance to families with a child diagnosed with schizophrenia in late adolescence or early adulthood, who is in treatment in routine psychiatric services which are unable but nevertheless value the opportunity to provide systematic assistance to families.

While the School applies several known professional and self-help approaches, its unique feature is that it uses the format of a boarding school, i.e., of a neutral territory, to provide learning experiences over the long period of one-and-a-half years. Frequent encounters at the School between parents and residents from different families provide the opportunity of 'experimenting' with and learning new behaviors and skills, mainly through 'learning by doing' and 'vicarious learning'. Since a group of 10 families begin the course at the same time, relationships of mutual support can develop and often remain after the end of the program. The main objective is that parents learn to keep the delicate balance between caring and letting their child live in autonomy (a concept called 'protected autonomy') and to assist residents in developing skills for an autonomous life after the School.

The School has seen around 230 families finish the course since its foundation in 1986. Since it was not set up as a research project, no continuous evaluation was performed, but there are a few illustrative data. A threeyear follow-up study on the first five courses (1986 to 1994) showed large improvements in the well-being and living situation of ex-residents and parents on several parameters. An anonymous assessment of the four most recent courses (2015-2021) by parents demonstrates high satisfaction with what they have learned (for details and references, see Supplementary materials).

In practice, there are several limitations. First, the School is not suited for all families. When parents work full-time, participation is not possible, since at least one parent has to come to the School regularly. Second, both the potential residents and the parents have to agree (and sign a contract) to participate, and this agreement is carefully evaluated by the staff. Over the last 35 years, around one in five families dropped out during the first few weeks of the program and were replaced by families on the waiting list. The most frequent reason for dropping out was that the residents did not want to continue since they regarded the program as too burdensome and ended their participation by simply not returning to the School after a weekend. Another reason for dropping out was that residents, contrary to before entering the School, suddenly feared a delay in obtaining a degree or missing out on a training or a job opportunity. Severity of the disease in terms of positive, negative or cognitive symptoms could be an exclusion criterion, but not necessarily so. In contrast to the ideal picture of daily routine drawn above, it is often the case that limitations arise in coordinating 10 families for the program. While keeping to the basic philosophy of the School, the staff have to be extremely flexible and willing to compromise, e.g., in cases where parents cannot come to the School for an agreed activity or where residents cannot participate in a planned activity because of an outside medical or psychiatric appointment. In rare instances, a short hospital admission might become necessary during the program, but in these cases the place is kept open for the resident. In recent years, the risk of using drugs has been increasing in young people diagnosed with schizophrenia, which often leads to difficult decisions about whether or not to admit a family.

\section{Manuscript process:}

Submitted: 01.08.2021

Accepted: 08.09.2021

Published: 30.09 .2021

Funding: The research was carried out without additional funding.

Conflict of interests: Authors declare no conflict of interest.

Authors' contribution: H. Katschnig - article writing, codevelopig the concept; P. Sint — reviewing publications of the article's theme, codeveloping the concept.

Acknowledgements: We thank Helmuth Michelbach (social worker; head of staff of the school from 1986 to 2003) and Monika Baumgartner (MSc Psychology; head of staff of the school from 2003 to date) for their steady and proficient efforts in running the school over the last decades. We also thank Teresa Konieczna (PhD 
Psychology and MD) for her input in the original planning stage of the school.

\section{Correspondence to:}

\section{Heinz Katschnig}

heinz.katschnig@meduniwien.ac.at

\section{For citation:}

Katschnig H, Sint P. Late 'Early Intervention in Psychosis': A Family School for Learning How to Live with Schizophrenia. Consortium Psychiatricum. 2021;2(3):3-16. DOI:10.17816/CP99

\section{Appendix A. Supplementary data}

Supplementary material related to this article can be found, in the online version, at doi:DOI:10.17816/CP99

\section{References}

1. Eassom E, Giacco D, Dirik A, Priebe S. Implementing family involvement in the treatment of patients with psychosis: a systematic review of facilitating and hindering factors. BMJ Open. 2014;4(10):e006108. doi:10.1136/bmjopen-2014-006108

2. Norman RM, Malla AK. Duration of untreated psychosis: a critical examination of the concept and its importance. Psychol Med. 2001;31(3):381-400. doi:10.1017/s0033291701003488

3. Lasalvia A, Vita A, Bellomo A, et al. Renaming schizophrenia? A survey among psychiatrists, mental health service users and family members in Italy. Schizophr Res. 2021;228:502-509. doi:10.1016/j. schres.2020.03.047

4. Kübler-Ross E. On Death and Dying. Routledge; 1969.

5. Koike S, Yamaguchi S, Ojio Y, et al. Long-term effect of a name change for schizophrenia on reducing stigma. Soc Psychiatry Psychiatr Epidemiol. 2015;50(10):1519-1526. doi:10.1007/s00127-015-1064-8

6. Yvon F, Prouteau A. Vers une compréhension de la stigmatisation : quel est le stéréotype associé à la schizophrénie ? Santé mentale au Québec. 2017;42(2):125-131. doi:10.7202/1041919ar

7. Schizophrenia: DSM-5 Definition. Accessed August 10, 2021. https://pro.psycom.net/assessment-diagnosis-adherence/ schizophrenia

8. Bleuler M. Die schizophrenen Geistesstörungen im Lichte langjähriger Kranken- und Familiengeschichten. Thieme; 1972.

9. Ciompi L, Müller Ch. Lebensweg und Alter der Schizophrenen. Eine katamnestische Langzeitstudie bis ins Senium. Vol 12. Springer; 1976.

10. Harding CM, Brooks GW, Ashikaga T, Strauss JS, Breier A. The Vermont longitudinal study of persons with severe mental illness, II: Long-term outcome of subjects who retrospectively met DSM-III criteria for schizophrenia. Am J Psychiatry. 1987;144(6):727-735. doi:10.1176/ajp.144.6.727

11. Häfner $\mathrm{H}$, an der Heiden $\mathbf{W}$. The course of schizophrenia in the light of modern follow-up studies: the ABC and WHO studies. Eur Arch Psychiatry Clin Neurosci. 1999;249 Suppl 4:14-26. doi:10.1007/ pl00014180

12. Jaaskelainen $E$, Juola $P$, Hirvonen $N$, et al. A systematic review and meta-analysis of recovery in schizophrenia. Schizophr Bull. 2013;39(6):1296-1306. doi:10.1093/schbul/sbs130

13. Zipursky RB, Reilly TJ, Murray RM. The myth of schizophrenia as a progressive brain disease. Schizophr Bull. 2013;39(6):1363-1372. doi:10.1093/schbul/sbs135

14. Lang FU, Muller-Stierlin AS, Walther S, et al. Psychopathological Symptoms Assessed by a System-Specific Approach Are Related to Global Functioning in Schizophrenic Disorders. Psychopathology. 2016;49(2):77-82. doi:10.1159/000444505

15. Vita A, Barlati S. Recovery from schizophrenia: is it possible? Curr Opin Psychiatry. 2018;31(3):246-255. doi:10.1097/ YCO.0000000000000407

16. Katschnig H. Psychiatry's contribution to the public stereotype of schizophrenia: Historical considerations. J Eval Clin Pract. 2018;24(5):1093-1100. doi:10.1111/jep.13011

17. Shmukler AB. The Evolution of Approaches to Schizophrenia Diagnostics: from Kraepelin to ICD-11. Consort Psychiatr. 2021;2(2):6570. doi:10.17816/cp62

18. Katschnig H, Konieczna T. What Works in Work with Relatives? A Hypothesis. Br J Psychiatry. 2018;155(S5):144-150. doi:10.1192/ s000712500029613x

19. Fromm-Reichmann F. Notes on the Development of Treatment of Schizophrenics by Psychoanalytic Psychotherapy. In: Bullardand DM, Weigert EV, eds. Psychoanalysis and Psychotherapy. University of Chicago Press;1952:263-274.

20. Cooper D. The Death Of The Family. Allen Lane; 1971.

21. Pringle John. John Pringle's letter. Accessed August 10, 2021. https://www.rethink.org/aboutus/who-we-are/our-history/johnpringles-letter

22. Pringle J, Pyke-Lees P. Voluntary action by relatives and friends of schizophrenia sufferers in Britain. Schizophr Bull. 1982;8(4):620-625. doi:10.1093/schbul/8.4.620

23. Allerby K, Sameby B, Brain C, et al. Stigma and Burden Among Relatives of Persons With Schizophrenia: Results From the Swedish COAST Study. Psychiatr Serv. 2015;66(10):1020-1026. doi: 10.1176/ appi.ps.201400405

24. Leff J, Vaughn C. The role of maintenance therapy and relatives' expressed emotion in relapse of schizophrenia: a two-year follow-up. BrJ Psychiatry. 1981;139:102-104. doi:10.1192/bjp.139.2.102

25. Anderson CM, Hogarty GE, Reiss DJ. Family treatment of adult schizophrenic patients: a psycho-educational approach. Schizophr Bull. 1980;6(3):490-505. doi:10.1093/schbul/6.3.490

26. Hogarty GE, Anderson CM, Reiss DJ, et al. Family psychoeducation, social skills training, and maintenance chemotherapy in the aftercare treatment of schizophrenia. I. One-year effects of a controlled study on relapse and expressed emotion. Arch Gen Psychiatry. 1986;43(7):633-642. doi:10.1001/archpsyc.1986.01800070019003

27. Leff J, Kuipers L, Berkowitz R, Eberlein-Vries R, Sturgeon D. A controlled trial of social intervention in the families of schizophrenic patients. Br J Psychiatry. 1982;141:121-134. doi:10.1192/bjp.141.2.121

28. Falloon IR, Boyd JL, McGill CW, et al. Family management in the prevention of exacerbations of schizophrenia: a controlled study. N EnglJ Med. 1982;306(24):1437-1440. doi:10.1056/ NEJM198206173062401

29. Goldstein MJ, Kopeikin HS. Short- and long-term effects of combining drug and family therapy. In: Goldstein MJ, ed. New Developments in Interventions with Families of Schizophrenics. Jossey-Bass;1981:5-26.

30. Katschnig $H$, Konieczna $T$, Michelbach $H$, Sint P. Ein familienorientiertes Wohnheim für schizophrene Patienten. In: Katschnig H, ed. Die andere Seite der Schizophrenie - Patienten zu Hause. 3., erweiterte Auflage. Psychologie Verlags Union; 1989:229-242.

31. McGorry PD, Killackey E, Yung A. Early intervention in psychosis: concepts, evidence and future directions. World Psychiatry. 2008;7(3):148-156. doi:10.1002/j.2051-5545.2008.tb00182.x 
32. Amering M, Schmolke M. Recovery in Mental Health: Reshaping Scientific and Clinical Responsibilities. Wiley-Blackwell; 2009.

33. Amering M. Trialogue: An Exercise in Communication Between Users, Carers, and Professional Mental Health Workers Beyond Role Stereotypes. In: Gaebel W, Rössler W, Sartorius N, eds. The Stigma of Mental IIIness - End of the Story? Springer;2016:581-590.

34. Katschnig H, Freeman HL, Sartorius N, eds. Quality of Life in Mental Disorders. 2nd ed. Wiley; 2006.

35. United Nations. Convention on the Rights of Persons with Disabilities (CRPD). Accessed August 10, 2021. https://www.un.org/ development/desa/disabilities/convention-on-the-rights-ofpersons-with-disabilities.html

36. Kuipers E, Leff J, Lam D. Family Work for Schizophrenia A Practical Guide. 2nd edition. Gaskell; 2016.

37. Katschnig $\mathrm{H}$, Konieczna $\mathrm{T}$. The philosophy and practice of self-help for relatives of the mentally ill. In: Strauss JS, Böker W, Brenner HD, eds. Psychosocial Treatment of Schizophrenia. Hans Huber Publishers; 1987:191-200.

38. Rogers CR. The necessary and sufficient conditions of therapeutic personality change. J Consult Psychol. 1957;21(2):95-103. doi:10.1037/ h0045357

39. Birchwood M, Todd $\mathrm{P}$, Jackson C. Early intervention in psychosis. $\mathrm{Br}$ J Psychiatry. 2018;172(S33):53-59. doi:10.1192/s0007125000297663

40. Zubin J, Spring B. Vulnerability: A new view of schizophrenia. J Abnorm Psychol. 1977;86(2):103-126. doi:10.1037/0021-843x.86.2.103
41. Falloon IRH, Boyd JL, McGill CW. Family Care of Schizophrenia. The Guilford Press; 1984.

42. Wing JK. Psychosocial factors affecting the long-term course of schizophrenia. In: Strauss JS, Böker W, Brenner HD, eds. Psychosocial Treatment of Schizophrenia. Hans Huber Publishers;1987:13-29.

43. Wing J, Brown G. Institutionalism and Schizophrenia: A Comparative Study of Three Mental Hospitals, 1960-1968. Cambridge University Press; 1970.

44. Brown GW, Birley JLT. Crises and Life Changes and the Onset of Schizophrenia. J Health Soc Behav. 1968;9(3):203. doi:10.2307/2948405

45. Sibitz I, Katschnig H, Goessler R, Unger A, Amering M. Pharmacophilia and pharmacophobia: determinants of patients' attitudes towards antipsychotic medication. Pharmacopsychiatry. 2005;38(3):107-112. doi:10.1055/s-2005-864119

46. Rosenmayer L, Köckeis, E. Umwelt und Familie alter Menschen. Luchterhand; 1965.

47. Kurtz MM. Symptoms versus neurocognitive skills as correlates of everyday functioning in severe mental illness. Expert Rev Neurother. 2006;6(1):47-56. doi:10.1586/14737175.6.1.47

48. Roder V, Mueller DR, Mueser KT, Brenner HD. Integrated psychological therapy (IPT) for schizophrenia: is it effective? Schizophr Bull. 2006;32 Suppl 1:S81-93. doi:10.1093/schbul/sbl021 